\title{
Olga Dąbrowska-Cendrowska
}

Uniwersytet Jana Kochanowskiego w Kielcach

ORCID: 0000-0002-7527-3789

\section{Sylwetki polityków na łamach luksusowych magazynów adresowanych do kobiet w Polsce w latach 1989-2018. Analiza porównawcza}

\begin{abstract}
Streszczenie
Prasa kobieca, jako składnik polskiego systemu medialnego, była analizowana przez reprezentantóu różnych dyscyplin naukowych. Badano między innymi: jej zawartość tematyczną, cechy formalne poszczególnych magazynów, kuestie własnościoue, problemy definicyjne, wewnętrzną subsegmentację itd. Omówione w tym artykule badania stanowią próbę uzupełnienia luki w analizach zawartości prasy kobiecej. Dlatego celem są syluetki polityków publikowane w magazynach luksusowych w latach 1989-2018. Próbę dobrano celowo, tj. uybrano 10 magazynów, z których osiem należało do firm z zagranicznym kapitałem (5 z niemieckim, 3 ze szuajcarskim). Do polskich uydawców należały dua periodyki. Z tego powodu istotnym elementem, branym pod uwagę u analizie materiałów, była narodowość kapitału kształtującego rynek polskiej prasy kobiecej. Cele szczegółowe to: dynamika zmian u sposobie prezentacji syluetek polityków, dominujące postaci, stosunek ilościouy między reprezentantami polskiej i zagranicznej sceny politycznej, analiza ilościoua ze względu na płeć i wiek prezentowanych polityków.
\end{abstract}

Słowa kluczowe: magazyny kobiece, syluetki polityków, segmentacja.

\section{The profiles of politicians in luxury magazines addressed to women in Poland in 1989-2018. Comparative analysis}

\begin{abstract}
Women's press, as the element of Polish media system, was analysed by representatives of various field studies. They focused on both its content, formal features, ounership issues, definition problems and internal subsegmentation. This research is an attempt to fill the gap in the studies of women's press content. For this reason, the main goal of this presentation is to analyse the profiles of politicians in luxury magazines in years 1990-2019. The research sample was chosen deliberately. It consists of 10 magazines. Eight of them belong to companies with foreign capitals (German - 5, Suiss - 3) and two belong to Polish ones. This means that nationality of the publishers, as an important element shaping women's press market, was taken into consideration.

Specific research goals: the dynamics of changes in the way politicians' profiles were presented, dominant characters, quantitative relations between the profiles of Polish and foreign politicians, quantitative analysis of politicians gender and age;
\end{abstract}

Keywords: women's magazines, profiles of politicians, segmentation. 


\section{Wprowadzenie}

Prasa kobieca to ważny element systemu medialnego, który ulega systematycznym przeobrażeniom wywołanym przez rozwój nourych technologii informacyjno-komunikacyjnych. Mimo zmian u odbiorze i użytkowaniu mediów oraz dominacji zdigitalizowanej oferty medialnej uciąż podejmuje się badania nad prasą kobiecą, którą ułaściciele permanentnie dostosourują do zmieniającego się ekosystemu medialnego, potrzeb konsumentów, przemian demograficznych w poszczególnych krajach oraz warunków rynkouych. Dla wielu odbiorców magazynowa formuła nasycona treścią i obrazem jest nadal atrakcyjna, o czym świadczą wyniki ze sprzedaży egzemplarzowej. Z pewnością nie tak wysokie, jak na początku XXI wieku, ale pozwalające generować zyski właścicielom.

Prasa kobieca była przedmiotem badań reprezentantów różnych dyscyplin naukowych. Badacze zajmowali się jej zawartością tematyczną ${ }^{1}$, historią i cechami formalnymi poszczególnych magazynów², kwestiami dotyczącymi własności ${ }^{3}$ oraz wewnętrzną subsegmentacją ${ }^{4}$. Podejmowano także próby rozstrzygnięcia problemów zuiązanych zarówno z typologią, jak i definiowaniem prasy kobiecej ${ }^{5}$.

Analizując literaturę przedmiotu, dostrzega się lukę związaną z tematyką dotyczącą szeroko rozumianej polityki na łamach magazynów adresowanych do kobiet ${ }^{6}$. Taka sytuacja może nie budzić żadnych wątpliwości. Pouszechnie prasa kobieca nie realizuje funkcji informacyjnych związanych $\mathrm{z}$ dostarczaniem bieżących treści, w tym tych

${ }_{1}$ Zob. m.in.: K. Wodniak, Wspótczesna prasa kobieca a sprawy książki, Stowarzyszenie Bibliotekarzy Polskich, Warszawa 2004; E. Zierkiewcz, Prasa jako medium edukacyjne. Kulturowe reprezentacje raka piersi $w$ czasopismach kobiecych, Oficyna Wydawnicza Impuls, Kraków 2013; Ch. Reynolds, S. LoRusso, The women's magazines diet: frames and sources in nutrition and fitness articles, „Journal of Magazines and New Media Research” 2016, nr 1, s. 4-21.

2 Z. Sokól, Prasa kobieca w Polsce w latach 1945-1995, Wydawnictuo Wyższej Szkoły Pedagogicznej, Rzeszów 1995; K. Gajlewicz-Korab, Francuska prasa drukowana. Narodziny, rozwój, era cyfrowa, Wydawnictwo Aspra JR, Warszawa 2018, s. 171-175, 201-205.

${ }^{3}$ Zob. m.in.: O. Dąbrowska-Cendrowska, Niemieckie koncerny prasowe $w$ Polsce $w$ latach 1989-2008. Działalność wydawnicza, upowszechnianie treści, sposoby oddziaływania na czytelników, Wydawnictwo Elipsa, Warszawa 2009; M. Adamik-Szysiak, Grupa Bauer Media w Polsce. Działalność i kierunek rozwoju [w:] Inwestycje koncernów na polskim rynku medialnym. Wybrane zagadnienia, red. L. Pokrzycka, Wydawnictuo Uniwersytetu Marii Curie-Skłodouskiej, Lublin 2012, s. 51-96.

4 Zob. m.in.: E. Zierkiewicz, Prasa kobieca versus pisma feministyczne. Między „dobrowolnym” zniewoleniem a „wymuszona” emancypację? [w:] Kobiety w kulturze popularnej, red. E. Zierkiewicz, I. Koualczyk, Wydaunictuo Konsola, Wrocław 2002; O. Dąbrouska-Cendrouska, W stronę sprofilowanego odbiorcy mediów, „Rocznik Bibliologiczno-Prasoznawczy” 2012, nr 15, s. 71-86.

5 A.-O. Irimescu, Women's magazines. Editorial practices and cultural recommendations, „Journal of Media Research” 2015, nr 8, s. 41-53; M.I. Menèndez, Tipologia de la prensa femenina. Una propuesta de clacificatión, „Estudios sobre de Mensaje Periodistico” 2013, nr 1, s. 191-206; R. Filas, Polskie czasopisma w XXI wieku - rozwój czy kryzys, „Zeszyty Prasoznawcze" 2007, nr 1-2, s. 7-41.

${ }^{6}$ O kobietach u polityce zob. m.in.: E. Maj, „Feminizm narodowy”, czyli o kobietach w Narodowej Demokracji [w:] Feminizm, red. M. Marczeuska-Rytko, D. Maj, M. Pomarański, Wydawnictwo Uniwersytetu Marii Curie-Skłodouskiej, Lublin 2015, s. 216-229. 
ze śuiata polityki. To domena prasy codziennej i tygodników opiniotwórczych. Jednak spojrzenie na ten segment prasowy przez pryzmat personalizacji treści, która w każdej grupie periodyków, w zależności od ich jakości, przebiega inaczej, sprawia, że można dostrzec politykę przez pryzmat prezentowanych sylwetek polityków.

Artykuł stanowi zatem próbę uzupełnienia tej luki w badaniach nad czasopismami adresowanymi do kobiet, a dokładnie u grupie magazynów luksusouych, które badacze nazywają także tymi z „najuyższej półki”7. Starano się odpowiedzieć na następujące pytania: jak kształtowała się dynamika zmian w sposobie prezentacji syluetek polityków w latach 1989-2018, jakie postaci dominowały, jak wyglądał stosunek ilościouy między reprezentantami polskiej i zagranicznej sceny politycznej oraz jak uyglądała ilościowa reprezentacja ze uzględu na płeć prezentowanych polityków.

Zakres chronologiczny rozważań wyznaczają 1989 i 2018 rok. Pierusza z uymienionych dat nie podlega dyskusji. Rok 1989 zapoczątkował gruntowną modernizację systemu społeczno-politycznego oraz norm prawnych regulujących funkcjonowanie środków masouego przekazu, w tym także magazynów wysokonakładouych. W 1990 roku ukazał się pieruszy numer miesięcznika „Twój Styl”, którego niezuykła popularność utorowała drogę kolejnym luksusowym magazynom. W 1991 roku redakcje przekształciły kwartalnik „Pani” oraz tygodnik „Zwierciadło” w miesięczniki. W 1994 roku zadebiutowała „Elle”. Tym sposobem na polskim rynku prasowym zadomowił się subsegment prasy kobiecej z „najwyższej półki”. Rok 2018 ma znaczenie umoune. Stanowi on swoisty kompromis pomiędzy jak największą aktualnością opracowania, a formalnymi i technicznymi uwarunkowaniami związanymi z procesem wydawniczym. Należy podkreślić, że trzydziestoletnia perspektywa czasowa pozwoliła uchuycić dynamikę prezentowania syluetek polityków na łamach magazynów luksusouych.

\section{Magazyny luksusowe dla kobiet - charakterystyka subsegmentu}

Magazyny luksusowe ${ }^{8}$ na polskim rynku medialnym to niezuykle interesujący i rozwijający się segment prasouy. Badacze prasy twierdzą, że czasopisma te kształtują określone postawy społeczne, normy i zuyczaje oraz styl życia osobistego i zawodowego ${ }^{9}$. Małgorzata Lisouska-Magdziarz pisze:

\footnotetext{
7 Zdecydowano się zaprezentować wyniki badań u tej grupie periodyków ze uzględu na wymogi formalne. Badania są częścią szerszego projektu, którym zostały objęte uszystkie magazyny wielotematyczne (23 tytuły z trzech subsegmentów, tj. prasa poradnikowo-rozrywkowa, miesięczniki poradnikowe i magazyny luksusowe) oraz duie grupy tematyczne: magazyny typu people (6 periodyków) oraz prasa rozrywkowo-plotkarska (8 tytułów). W projekcie przewidziano także poróunanie segmentu magazynóu luksusowych dla kobiet i mężczyzn pod względem prezentacji syluetek polityków.

${ }_{8}$ Autorka używa zamiennie określenia „ekskluzywne”.

9 Zob. też.: T. Mielczarek, Monopol, pluralizm, koncentracja, op. cit., s. 171-190; E. Zierkiewicz, Czasopisma life-stylowe dla mężczyzn - (pozorna) opozycja dla prasy kobiecej, „Studia Socjologiczne" 2008, nr 1, s. 45-75.
} 


\section{Olga Dąbrowska-Cendrowska}

wolny rynek doprowadził do poustania mediów rodzajouych, do których niewątpliwie należą luksusowe magazyny dla kobiet. Wyniki badań marketingouych stały się podstawą do profilowania rodzajowego, które uyraża się u tym, że media selekcjonują i kształtują swoją zawartość stosownie do domniemanych kobiecych lub męskich preferencji, zainteresowań, gustów i potrzeb emocjonalnych oraz estetycznych. Tym samym na swoich łamach proponują określony styl życia uyraźnie skorelowany z zasobnością portfela ${ }^{10}$.

Mateusz Nieć zauważa, że grupa docelowa magazynów luksusowych to: „zarówno kobiety, jak i mężczyźni, zamożni lub średniozamożni, dobrze wykształceni, aktyuni zawodowo lub publicznie"11.

Biorąc pod uwagę zawartość luksusowe periodyki kobiece („najuyższa półka”) razem z miesięcznikami poradnikowymi (,środkowa półka”) i prasą poradnikowo-rozrywkową („najniższa półka”) należą do magazynów ogólnotematycznych lub - jak określa je Zofia Sokół - wielotematycznych ${ }^{12}$. Na ich łamach redakcje poruszały tę samą tematykę, lecz dostosowaną do sprecyzowanej grupy docelowej. Najistotniejsze zagadnienia dotyczą zdrowia, relacji interpersonalnych, wychowania dzieci, kulinariów, kultury, życia znanych i zwykłych osób. W subsegmencie magazynów luksusowych do tej grupy należeli także politycy. Co istotnie, ani w miesięcznikach poradnikowych („Claudia”, „Świat Kobiety”, „Olivia”, „Kobieta i Życie”, „Poradnik Domowy”, „Dobre Rady”, ani w prasie poradnikowo-rozrywkowej („Tina”, „Przyjaciółka”, „Naj”, „Pani Domu”, „100 Rad”, „Poradnik 50+”, „Cała Ty”) w latach 1989-2018 nie opublikowano żadnych informacji dotyczących postaci związanych z polską lub zagraniczną sceną polityczną. Wydaje się, że redakcje magazynów lub/i ich wydawcy przyjęli założenie, że w spektrum zainteresowań „praktycznej Polki” skoncentrowanej na funkcjonowaniu domu i rodziny, muszącej sprostać codziennym obowiązkom, nie znajdują się informacje związane z życiem polityków ${ }^{13}$.

W latach 1989-2018 segment magazynów luksusowych dla kobiet tworzyło 11 periodyków ${ }^{14}$. Po trzy tytuły miały firmy Burda International oraz Bauer Media. Do pieruszej z nich należały: „In Style”, „Glamour” i „Elle”. Do drugiej: „Twój Styl”, „Pani” i najmłodszy na rynku „Well”. Marquard Media zaoferował czytelniczkom „Cosmopolitan” i „Joy”. Po jednym tytule miały Agora Sp. z o.o. - „Wysokie Obcasy Extra”, Wydawnictwo Zwierciadło - „Zuierciadło” i Edipresse Polska - „Urodę Życia”.

${ }_{10}$ M. Lisouska-Magdziarz, Media powszechne. Środki komunikowania masowego i szerokie paradygmaty medialne $w$ życiu codziennym Polaków u progu XXI wieku, Wydawnictwo Uniwersytetu Jagiellońskiego, Kraków, 2008, s. 285-286.

${ }^{11}$ M. Nieć, Pisma opinii i czasopisma life style - dwie koncepcje rynkowego dziennikarstwa (analiza Polityki, Wprost, Elle, Playboya i Twojego Stylu), „Zeszyt Prasoznawcze” 2010, nr 1/2, s. 23.

12 Z. Sokól, Prasa kobieca w Polsce..., op. cit., s. 8.

${ }^{13}$ Badaniom poddano uszystkie wymienione tytuły. Badaniami z autopsji objęto każdy numer z 7 periodyków ukazujących się w przyjętym okresie.

14 Autorka skoncentrowała się na magazynach, które pojawiły się na polskim rynku prasowym w latach 1990-2015 i nie zostały zlikwidowane lub zawieszone. Śuiadomie pominęła miesięcznik „Mari Clair”, który mimo trzech prób nie zadomowił się na rynku oraz ukazujący się jedynie przez pół roku magazyn „Amelia”. 
Warto podkreślić, że mimo trudnej sytuacji na rynku prasowym uydawcy nie rezygnowali z wprowadzania nowych tytułów. W 2014 roku zadebiutowała „Uroda Życia”, którą redakcja zaadresowała do kobiet „powyżej 50 roku życia, które chcą od życia czegoś więcej”" W lutym 2018 roku Bauer poszerzył ofertę o „Well”. Magazyn miał się upisać w strategię inwestowania w rodzime marki, a nie pisma na licencji ${ }^{16}$. Jednak w maju 2018 roku periodyk został zlikwidowany, a ze uspółpracy z firmą wycofała się redaktor magazynu, Dorota Wellman. W tabeli 1 zaprezentowano magazyny luksusowe dla kobiet ukazujące się na polskim rynku w latach 1990-2018.

Tabela 1. Segment magazynóu luksusouych dla kobiet

\begin{tabular}{|c|c|c|c|c|}
\hline L.p. & Tytuł & $\begin{array}{c}\text { Rok } \\
\text { poustania }\end{array}$ & Wydawca & $\begin{array}{c}\text { Redaktor naczelny } \\
\text { w } 2018 \text { roku }\end{array}$ \\
\hline 1 & „Twój Styl” & $\begin{array}{l}1990 \\
2002\end{array}$ & $\begin{array}{l}\text { Wydawnictuo Prasoue „Twój } \\
\text { Styl” } \\
\text { Bauer Media }\end{array}$ & Jacek Schmidt \\
\hline 2 & „Pani" & $\begin{array}{l}1991 \\
2005\end{array}$ & $\begin{array}{l}\text { Agencja Wydauniczo-Reklamowa } \\
\text { „Wprost” } \\
\text { Bauer Media }\end{array}$ & Monika Stukonis \\
\hline 3 & „Zuierciadło” & 1994 & Zuierciadło sp. z o.o. & Paulina Stolarek \\
\hline 4 & „Elle” & $\begin{array}{l}1994 \\
2006 \\
\end{array}$ & $\begin{array}{l}\text { Hachette Filipacchi } \\
\text { Burda International }\end{array}$ & Marta Drożdż \\
\hline 5. & „Cosmopolitan” & 1997 & Marquard Media Polska & Joanna Mroczkouska \\
\hline 6. & "Glamour" & 2003 & Burda International & Katarzyna Dąbrouska \\
\hline 7. & „Joy” & 2006 & Marquard Media Polska & Martyna Zagórska \\
\hline 8. & "In Style" & $\begin{array}{l}2008 \\
2018 \\
\end{array}$ & $\begin{array}{l}\text { Burda International } \\
\text { Likwidacja pisma }\end{array}$ & Anna Zejdler-Ibisz \\
\hline 9. & „Wysokie Obcasy Extra” & 2010 & Agora SA & Ewa Wieczorek \\
\hline 10. & „Uroda Życia” & 2014 & Edipresse Polska & Anna Maruszeczko \\
\hline 11. & „Well” & $\begin{array}{l}2018 \\
2018\end{array}$ & $\begin{array}{l}\text { Bauer Media } \\
\text { Likwidacja pisma }\end{array}$ & Dorota Wellman \\
\hline
\end{tabular}

Źródło: badania własne.

\section{Politycy na łamach magazynów luksusowych - metodologia badań}

Badaniami objęto 10 magazynów należących do grupy periodykóu luksusouych. Zdecydowano się wyłączyć „Well” ze względu na to, że ukazały się jedynie trzy numery tego czasopisma. Jak już uspomniano, analiza zawartości wykazała, że w czterech magazynach luksusouych, tj. „Joy”, Cosmopolitan”, „Glamour” i „In Style” nie zamieszczano żadnych materiałów prezentujących syluetki polityków. Dlatego dalszym, szczegółouym badaniom poddano sześć periodyków, tj. „Twój Styl”, „Pani”, „Zuierciadło”, „Elle”, „Wysokie Obcasy. Extra” i „Uroda Życia”, na łamach których z różnym natężeniem prezentowano sylwetki polityków. Z tych sześciu tytułów cztery

15 „Uroda Życia” 2014, nr 1, s. 7.

${ }^{16}$ Należy dodać, że u 2018 roku z rynku zniknęła wydawana na licencji „Grazia”. 
należały do koncernów z zagranicznym kapitałem (3 z niemieckim, 1 ze szuajcarskim). W portfolio polskich wydauców znalazły się dwa czasopisma. Z tego powodu istotnym elementem branym pod uwagę w analizie materiałów była narodowość kapitału kształtującego rynek polskiej prasy kobiecej.

Chcąc uchwycić dynamikę zmian w sposobie prezentacji syluetek polityków w latach 1989-2018, uskazać dominujące postaci oraz reprezentantów polskiej i zagranicznej sceny politycznej, a także ilościową reprezentację ze uzględu na płeć, zdecydowano się na celouy dobór próby, którą stanowiły uszystkie numery wybranych magazynów. Łącznie korpus badawczy tworzyło: 341 numerów „Twojego Stylu”, 335 - „Pani”, 336 - „Zuierciadła”, 291 - Elle”, 79 - „Wysokich Obcasów. Extra”, 50 - „Urody Życia”. Tylko takie podejście do problemu pozwoliło na rzetelną analizę problemu badauczego. Przyjęto duie jednostki pomiaru. Po pierusze, artykuł, na łamach którego najczęściej publikowano informacje dotyczące jednego polityka. Zdarzały się też teksty prezentujące od dwóch do sześciu postaci. Były to suoistego rodzaju przeglądy. Po drugie, syluetkę polityka. Dlatego w ilościowej prezentacji wyników badań zdecydowano się na podanie uyników odnośnie do liczby artykułów, łącznej liczby wszystkich wymienionych postaci oraz poszczególnych postaci (bez powtórzeń).

Przyjęto założenie, że polityk to osoba, dla której zarządzanie władzą państwową jest pracą, zawodem, profesją, za którą otrzymuje wynagrodzenie. Do tej grupy celowo włączono pierusze damy oraz postaci z rodów króleuskich, które na łamach publikowanych artykułów były przedstawiane w kontekście sprawowanej funkcji.

\section{Wyniki badań}

Analiza wykazała, że segment magazynów luksusouych po względem prezentacji sylwetek polityków jest niejednorodny. Wyłonił się podział na dwie podgrupy. W sześciu czasopismach tzn.: „Twoim Stylu”, „Pani”, „Zwierciadle”, „Elle”, „Wysokich Obcasach. Extra” oraz Urodzie Życia” z różnym natężeniem prezentowano syluetki zaróuno polskich, jak i zagranicznych polityków. W różnych proporcjach syluetki kobiet i mężczyzn. Natomiast w czterech, tj. „Joy”, „In Style”, „Cosmopolitan” oraz „Glamour" nie zamieszczono żadnego artykułu poświęconego politykowi. Należy w tym miejscu podkreślić, że pod względem formalnym wszystkie wymienione tytuły można zaklasyfikować do subsegmentu magazynów luksusouych. Jednak analiza zawartości uwypukla wyraźne różnice. Pierwszą grupę tworzą klasyczne magazyny luksusowe, drugą te wyraźnie skoncentrowane na modzie, zakupach i konsumpcji. Pisma te przypominają raczej katalogi modowo-shoppingowe. Zdecydowanie uboższe $w$ materiały dziennikarskie prezentowane za pomocą różnych gatunków prasouych ${ }^{17}$.

Można przypuszczać, że przyczyną tego wewnętrznego podziału była odmiennie sprofilowana grupa docelowa. Klasyczne magazyny adresowano do kobiet powyżej

${ }_{17}$ Więcej na ten temat zob. O. Dąbrouska-Cendrouska, Czy prasa kobieca potrzebuje gatunków dziennikarskich, „Media i Społeczeństwo” 2016, nr 6, s. 183-197. 
35. roku życia, wykształconych, pracujących zawodowo, realizujących się w sferze prywatnej i publicznej, mających partnera lub męża oraz dzieci, aktyunych fizycznie i dbających o siebie. Grupę odbiorców „Joy”, „In Style”, „Cosmopolitan” oraz „Glamour" tworzyły zdecydowanie młodsze kobiety między 20. a 30. rokiem życia, także aktywne zawodowo, lecz najczęściej będące singielkami skoncentrowanymi na sobie. „Cosmopolitan” tak opisał suoje czytelniczki

jesteśmy dla tych kobiet, które chcą czerpać z życia to, co najlepsze, chcą wiedzieć, jak realizować marzenia i każdego dnia stawać się coraz lepszą wersją siebie. Otwarcie i bez tabu poruszamy najważniejsze tematy u życiu każdej kobiety. Cosmopolitan inspiruje, uspiera i informuje. A nasze czytelniczki to młode kobiety, świadome swojej wartości i potrzeb, to te kobiety, które poszukują nouych doświadczeń i wiedzy ${ }^{18}$.

Poróunując analizowane czasopisma należy pamiętać, że debiut niemal każdego z nich przypada na inny rok. „Twój Styl”, „Pani” i „Zuierciadło” to początek lat 90. XX wieku. Więc ich długość funkcjonowania jest podobna. Badano łącznie zbliżoną liczbę numerów. Wydaje się, że do tej grupy można dołączyć także rezultaty badań o trzy lata młodszej „Elle”. Zupełnie inaczej sytuacja kształtuje się w przypadku „Wysokich Obcasów. Extra” i „Urody Życia”, które w 2018 roku obchodziły odpowiednio ósme i czwarte urodziny. Ich krótsza historia to z założenia mniej wydanych numerów i mniej artykułów dotyczących polityków.

Pamiętając o tym, nie dziwi fakt, że na łamach „Twojego Stylu” opublikowano 61 artykułów prezentujących postaci polityków. Na drugim miejscu z wynikiem 53 artykułów uplasowała się „Pani”. Niemal o połowę mniej artykułóu pojawiło się w „Zwierciadle” i „Elle”. Analiza danych z tych czterech periodyków pozuala zauważyć wewnętrzne rozbieżności $w$ liczbie prezentowanych postaci ze świata polityki. Mimo zdecydowanie krótszej historii aż 19 artykułów zamieszczono w „Wysokich Obcasach. Extra".

Jak już uspomniano, najczęściej artykuły dotyczyły jednej osoby. Lecz zdarzały się także takie, które prezentowały od dwóch do sześciu postaci. W „Twoim Stylu” na łamach 61 artykułów 75 razy opisywano różnych polityków. Niektóre postaci gościły kilka razy w trzydziestoletniej historii pisma. Łącznie czytelniczkom przedstawiono syluetki 52 różnych polityków. Takich dużych różnic nie widać ani w „Zuierciadle”, ani w „Pani”. Można stuierdzić, że redakcje dbały o różnorodność. Nie chciały doprowadzić do dominacji jakiegoś polityka. W pierwszym z wymienionych periodyków w 22 artykułach 22 razy pisano o politykach. Przedstawiono 20 postaci. W drugim magazynie w 53 artykułach 58 razy pisano o osobach ze śuiata polityki. Przybliżono łącznie syluetki 49 różnych polityków. Już na tym etapie prezentowania wyników badań można stuierdzić, że redakcje „Twojego Stylu” i „Pani” zaprezentowały swoim czytelniczkom zbliżoną liczbę różnych polityków. Odpowiednio - 52 i 49.

${ }^{18}$ https://wuw.marquard.pl/magazyny/cosmopolitan (dostęp: 10.10.2019). 
Na łamach „Elle” i „Wysokich Obcasów. Extra” publikowano więcej artykułów traktujących o więcej niż jednej postaci. Miesięcznik Burdy International nie stronił od polityków zaangażowanych w politykę na szczeblach lokalnym i regionalnym. W rubryce „Historie kobiet” przybliżył czytelniczkom codzienne życie Billa de Blasio - burmistrza Nowego Yorku widziane oczami jego żony ${ }^{19}$. W dziale „Kobiety w polityce" zamieszczono informacje dotyczące Cristiny Fernandez de Kircher, będącej prezydentem Argentyny ${ }^{20}$, w rubryce „kariera” Anne Hidalgo - mera Paryża, Karin Wanngärd - burmistrza Sztokholmu, Patricie de Lille - burmistrza Kapsztadu, Clover Moore - burmistrza Sydney oraz Hanny Gronkiewicz-Walz ${ }^{21}$. W „Elle” na łamach 23 artykułów zaprezentowano syluetki 36 różnych polityków. Pięć postaci się poutórzyło. Łącznie o politykach pisano 41 razy.

Magazyn Agory „Wysokie Obcasy. Extra” wyspecjalizował się w materiałach opisujących pracę polityków, a właściwie polityczek. W cyklu „One rządzą światem” autor opisał: Angelę Merkel, Teresę May, Michelle Bachelet - pieruszą kobietę prezydenta Chile, Dalię Grybauskaite - prezydent Lituy, Park Geun-Hye - prezydent Korei Południowej, Ellen Johson-Sirleaf - prezydent Liberii, Erne Solberg - premier Norwegii, Kersti Kaijuland - prezydent Estonii oraz Małgorzatę II - królową Danii ${ }^{22}$. Dlatego różnica między liczbą publikowanych tekstów (19) a łączną liczbą wskazań uszystkich polityków (33) wyniosła 14. W „Wysokich Obcasach. Extra” zaprezentowano 30 różnych polityków. Co w przypadku ośmioletniej historii pisma upoważnia do stuierdzenia, że redakcja była zainteresowana kwestiami związanymi z polityką prezentowanymi przez pryzmat tych, którzy sprauują władzę.

Na łamach najmłodszego miesięcznika, tj. „Urody Życia”, opublikowano sześć artykułów, na łamach których przedstawiono siedem razy pisano o politykach. Przybliżono syluetki sześciu postaci. Duukrotnie napisano o Jacku Kuroniu. Na rycinie 1 zilustrowano omawiane wyniki badań.

W latach 1990-2018 redakcje z różnym natężeniem prezentowały artykuły z sylwetkami polityków. Można było przypuszczać, że rozwój ilościouy u segmencie magazynów luksusowych przełoży się bezpośrednio zarówno na wzrost liczby artykułów przedstawiających polityków, jak i na liczbę prezentowanych postaci. Analiza zebranego materiału pokazuje, że rocznie najczęściej prezentowano od sześciu do ośmiu artykułów. Najmniej po dwa materiały ukazały się u 1995 i 1996 roku. Należy przypomnieć, że to początek kształtowania się tego subsegmentu prasowego. Najuięcej, tj. 16 artykułów, opublikowano w 2017 roku. Prawie połowa (7) na łamach „Wysokich Obcasów. Extra”. Pisano o Robercie Biedroniu ${ }^{23}$, Królowej Wiktorii ${ }^{24}$, Donaldzie Trumpie $\left(2\right.$ razy ${ }^{25}$, Księciu

${ }_{19}$ B. Kachka, A. Bugajska, Żona burmistrz i Nowy York, „Elle” 2014, nr 4, s. 68-70.

${ }^{20}$ G. Plebanek, Po władze ze skalpelem, „Elle” 2013, nr 2, s. 78-81.

${ }^{21}$ Prezydentki, „Elle” 2016, nr 12, s. 108-113.

${ }^{22}$ N. Waloch-Matlakiewicz, One rzadza światem, „Wysokie Obcasy. Extra” 2016, nr 11, s. 58-61.

${ }^{23}$ K. Sulej, Prezydencie nie wypada, „Wysokie Obcasy. Extra” 2017, nr 11, s. 132-135.

${ }^{24}$ K. Wężyk, Kieszonkowy Herkules, „Wysokie Obcasy. Extra” 2017, nr 6, s. 78-84.

${ }^{25}$ M. Nogaś, Underwood wygratby z Trumpem, „Wysokie Obcasy. Extra” 2017, nr 5, s. 96-101; M. Staniszeuska, Jagodowa księżniczka, „Wysokie Obcasy. Extra” 2017, nr 4, s. 58-63. 
Sylwetki polityków na łamach luksusowych magazynów...

Karolu $^{26}$, Księżnej Dianie ${ }^{27}$ i Alice Roosevelt ${ }^{28}$. Na rycinie 2 przedstawiono ilościową dynamikę prezentacji artykułów z syluetkami polityków.

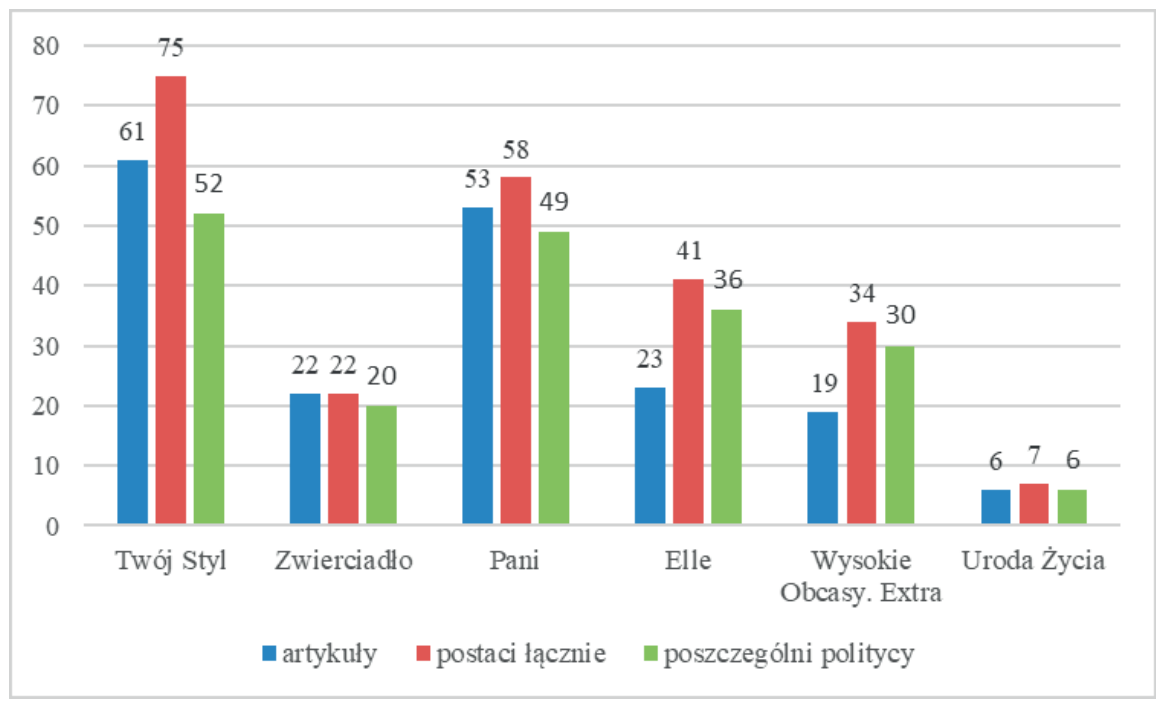

Rycina 1. Politycy na łamach magazynów luksusowych

Źródło: badania własne.



Rycina 2. Dynamika prezentacji artykułów z syluetami polityków u latach 1991-2018 Źródło: badania własne.

${ }^{26}$ M. Rachid Chehab, Książe Karol i prognoza pogody, „Wysokie Obcasy. Extra” 2017, nr 9, s. $46-47$.

${ }^{27}$ M. Rachid Chehab, Lady gadżet, „Wysokie Obcasy. Extra” 2017, nr 9, s. 48-53.

${ }^{28}$ K. Wężyk, Księżniczka Alice, „Wysokie Obcasy. Extra” 2017, nr 3, s. 84-90. 


\section{Olga Dąbrowska-Cendrowska}

Analizując zebrany materiał pod względem płci polityków widać wyraźnie, że w „Twoim Stylu”, „Pani” i w „Wysokich Obcasach. Extra” zdecydowanie dominowały kobiety. W najstarszym miesięczniku w „Twoim Stylu” przedstawiono 39 pań i 13 panów. Najczęściej pisano o Hillary Clinton (6 razy) ${ }^{29}$, Hannie Gronkiewicz-Walz $(4 \text { razy })^{30}$, Róży Thun (3 razy) $)^{31}$. Wśród mężczyzn najczęściej pisano o Billu Clintonie, zausze w kontekście jego żony Hillary (4 razy) ${ }^{32}$. Dua razy pisano o Aleksandrze Kuaśnieuskim $^{33}$, Władysłauie Bartoszeuskim ${ }^{34}$ i Robercie Biedroniu ${ }^{35}$.

W „Pani” zaprezentowano czytelniczkom 29 kobiet i 20 mężczyzn. Dua razy pisano o Hillary Clinton ${ }^{36}$ i Henryce Bochniarz ${ }^{37}$. Najpopularniejszym politykiem był Lech Wałęsa $(4 \text { razy) })^{38}$. Po dwa razy pisano o Donaldzie Tusku ${ }^{39}$ i Aleksandrze Kuaśniewskim ${ }^{40} w$ rubryce „Partnerzy”.

Podobnie proporcje ukształtowały się w „Wysokich Obcasach. Extra”, na łamach których poświęcono miejsce na syluetki 17 kobiet i 13 mężczyzn. W zuiązku z tym, że redakcja starała się prezentować różne postaci jedynie po dua razy napisano o Księżnej

${ }^{29}$ A. Romanouski, Hillary wygrana Clintona, „Twój Styl” 1993, nr 2, s. 176-179; M. Michałouska, Kobiety z przyszłościa, „Twój Styl” 1994, nr 10, s. 174-178; K. Rusin, Konfrontacja rywalek, „Twój Styl” 1996, nr 11, s. 70-74; A. Tomiak, Nie zobaczycie moich tez, „Twój Styl” 1998, nr 7, s. 95-98; T.B. Feldman, Chciałabym pogodzić świat, „Twój Styl” 2001, nr 3, s. 58-61; A. Tomiak, Czas na pierwsze damy, „Twój Styl” 2004, nr 2, s. 76-79.

30 J. Szmidt, Codziennie rachunek, „Twój Styl” 1993, nr 4, s. 14-19; B.N. Łopieńska, Złota próba, „Twój Styl” 1998, nr 9, s. 40-44; J. Szmidt, Zawsze gotowa, „Twój Styl” 2001, nr 2, s. 52-55; E. Królikowaska-Avis, Londyńska misja, „Twój Styl” 2002, nr 12, s. 70-75.

${ }^{31}$ A. Grigo, Europa w rodzinie, „Twój Styl” 2002, nr 12, s. 68-72; M. Jaros, Szczęście to w Róży, „Twój Styl” 2005, nr 12, s. 18-23; M. Bednarska, Bezczelna optymistka, „Twój Styl” 2014, nr 4, s. $66-72$.

${ }^{2}$ A. Romanouski, Hillary wygrana Clintona, „Twój Styl” 1993, nr 2, s. 176-179; K. Rusin, Konfrontacja rywalek, „Twój Styl” 1996, nr 11, s. 70-74; A. Tomiak, Nie zobaczycie moich tez, „Twój Styl” 1998, nr 7, s. 95-98; T.B. Feldman, Chciałabym pogodzić świat, „Twój Styl” 2001, nr 3, s. 58-61.

${ }^{33}$ Uderzamy dłonia w dłoń, „Twój Styl” 1997, nr 1, s. 40-41; A. Tomiak, Nie zobaczycie moich łez, „Twój Styl” 1998, nr 7, s. 95-98; A. Wlazły, Ani słowa o polityce, „Twój Styl” 1999, nr 12, s. 64-70.

${ }^{34}$ M. Bednarska, Bartoszewski bój się Boga, „Twój Styl” 2007, nr 5, s. 50-56; W. Staszeuski, Świat wedtug Zofii, „Twój Styl” 2017, nr 3, s. 92-96.

${ }_{35}$ J. Szmidt, Dobrze być soba, ,Twój Styl” 2015, nr 6, s. 62-66; A. Litorouicz-Siegert, A państwo tak razem, „Twój Styl” 2016, nr 2, s. 43-47.

${ }^{36}$ K. Kłopotouski, Kobieta z kauczuku, „Pani” 2000, nr 10, s. 20-24; K. Mroziewicz, Zawsze pierwsza, zawsze dama, „Pani” 2007, nr 1, s. 64-67.

${ }_{37}$ N. Iwaszkiewicz, Między wyciąniętą dtonią na nie zerwanym jabtkiem, „Pani” 1994, nr 7/8, s. 68-69; N. Iwaszkiewicz, Lubię świat i ludzi, „Pani” 2002, nr 4, s. 12-16.

${ }^{38}$ B. Henkel, Wspólne chwile i rozterki, „Pani” 1994, nr 4, s. 13-17; B. Hrybacz, Nie chciałam być sucha pania premier, „Pani” 1996, nr 12, s. 50-51 (Lecha Wałęsę uspomina Hanna Suchocka); S. Pinkwart, Portret wewnętrzny. Watęsa, „Pani” 2009, nr 10, s. 100-104; P. Adamowicz, Danuta Watęsa, „Pani” 2009, nr 6, s. 91-95.

${ }^{39}$ B. Szczupeł, Dom rodzinny Donalda Tuska, „Pani” 1992, nr 12, s. 30-32; B. Henkel, W mtodości hierarchie tańcza jak zwariowane, „Pani” 2003, nr 7, s. 28-32.

${ }^{40}$ B. Hankel, Pielęgnowanie uczuć, „Pani” 2001, nr 5, s. 10-14; M. Domagalik, Nie sztuka wygrać, gdy się jest najlepszym, „Pani” 2006, nr 1, s. 68-73. 
Dianie $^{41}$ i Angeli Merkel ${ }^{42}$ oraz o Robercie Biedroniu ${ }^{43}$ i Donaldzie Trumpie ${ }^{44}$. Tylko na łamach „Pani” pojawiły się obszerne artykuły w cyklu „Mistrz i Małgorzata”, w których redaktor naczelna Małgorzata Domagalik rozmawiała z Janem Marią Rokitą ${ }^{45}$ i Zbigniewem Ziobro ${ }^{46}$.

W „Zwierciadle” i „Urodzie Życia” przeważali mężczyźni. Warto u tym miejscu podkreślić, że jedynie na łamach „Zwierciadła” pojawiły się syluetki Wiktora Osiatyńskiego ${ }^{47}$, Władysława Frasyniuka ${ }^{48}$ i Grzegorza Kołodko ${ }^{49}$. Na rycinie 3 zaprezentowano ilościowy stosunek reprezentacji polityków płci żeńskiej i męskiej w badanych periodykach.

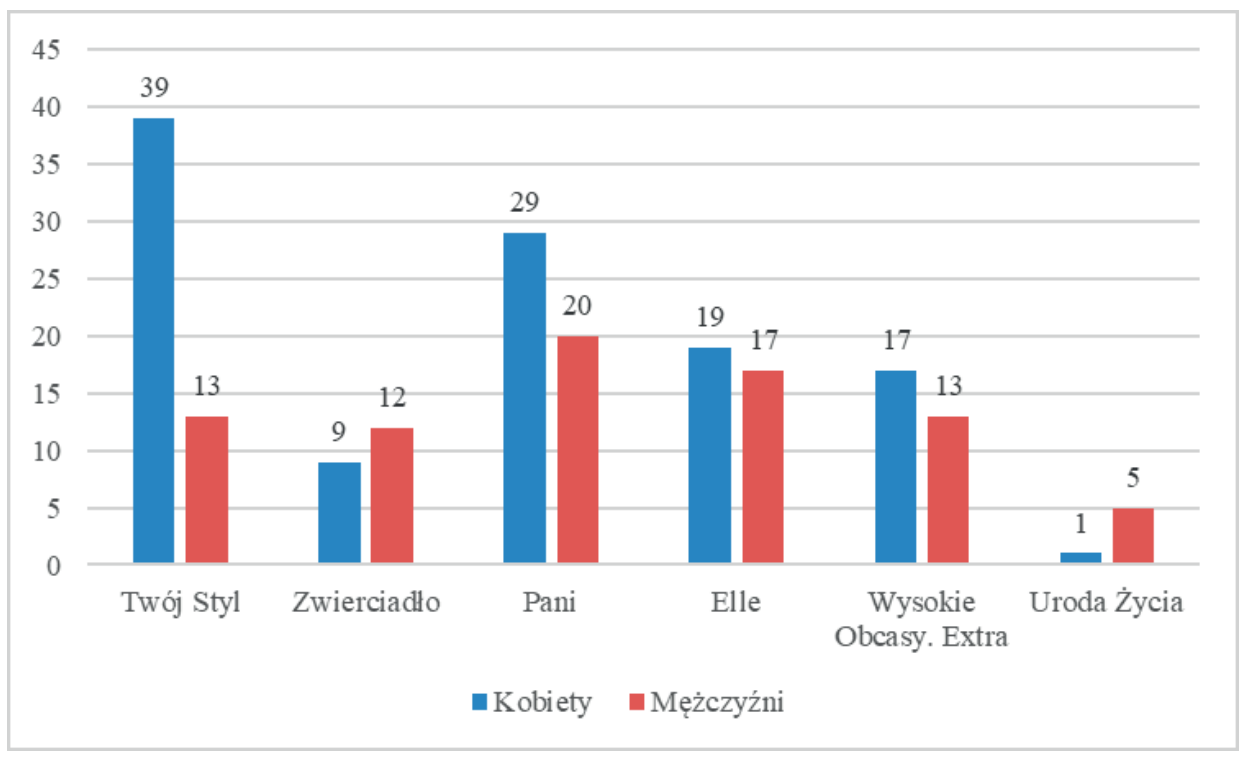

Rycina 3. Analiza porównawcza ze uzględu na płeć

Źródło: badania własne.

${ }^{41}$ A. Borowiec, Gdy księżniczka się nudzi, „Wysokie Obcasy. Extra” 2013, nr 5, s. 34-41; M. Rachid Chehab, Lady gadżet, „Wysokie Obcasy. Extra” 2017, nr 9, s. 48-53.

${ }^{42}$ N. Waloch-Matlakiewicz, One rzadza światem, „Wysokie Obcasy. Extra” 2016, nr 11, s. 58-61;

G. Giedrys, Wizerunkowy turniej garbusów, „Wysokie Obcasy. Extra” 2015, nr 10, s. 38-43.

${ }^{43}$ K. Sulej, Prezydencie nie wypada, „Wysokie Obcasy. Extra” 2017, nr 11, s. 132-135;

N. Waloch-Matlakiewicz, Luzuję gorset i robię swoje, „Wysokie Obcasy. Extra” 2016 nr 5, s. $48-55$.

${ }^{44}$ M. Nogaś, Underwood wygrałby z Trumpem, „Wysokie Obcasy. Extra” 2017, nr 5, s. 96-101; M. Staniszeuska, Jagodowa księżniczka, „Wysokie Obcasy. Extra” 2017, nr 4, s. 58-63.

${ }^{45}$ M. Domagalik, Byt kandydatem na maminsynka, „Pani” 2004, nr 2, s. 50-55.

${ }^{46}$ M. Domagalik, Przyjemność, co ma pani na myśli, „Pani” 2004, nr 2, s. 50-55.

${ }^{47}$ M. Ruszpel, Lekcja feminizmu, „Zuierciadło” 2008, nr 8, s. 52-55.

48 Z. Fabianouska-Micyk, Frasyniuk cośmy najlepszego zrobili, „Zuierciadło” 2011, nr 8, s. $66-72$.

${ }^{49}$ W. Lipińska, 10 pytań do dwojga, „Zuierciadło” 1996, nr 8, s. 7-8. 
Analizując syluetki polityków prezentowane na łamach magazynów luksusowych przez pryzmat miejsca uprawiania polityki, widać trojakie podejście redakcji i wydawców. Pieruszą grupę tworzyły te miesięczniki, w których dominowały postaci z polskiej sceny politycznej. Taką strategię przyjęto w „Pani”, „Elle” i „Zwierciadle”. Należy w tym miejscu podkreślić, że dwa pierusze tytuły należały do niemieckich uydawców, trzeci z uymienionych do polskiej spółki.

W „Pani” proporcje między Polakami a obcokrajoucami wyniosły odpowiednio 32 do 17. Tylko na łamach „Pani” opublikowano artykuły o Hannie Suchockiej, Ewie Kopacz, Danucie Waniek, Annie Boguckiej-Skourońskiej, Małgorzacie Kidawie-Błońskiej czy Bronisławie Komorouskim. Duukrotnie pisano o Józefie Piłsudzkim i Donaldzie Tusku. Postaci uprawiających politykę na arenie innych krajach było zdecydowanie mniej. Redakcja zaprezentowała 16 sylwetek: Helmut Khol, Książę Albert, Vaclav Havel, Dagmara Pavlova, Magda Vasaryova, Varia Vike-Freiberg, Hillary Clinton, Nadjeżda Michajłowa, Julia Tymoszenko, Michaił Gorbaczow, Raisa Gorbaczow, Barack Obama, Margaret Thatcher, Michael Obama, Vladimr Putin, Elżbieta II.

W „Elle” przybliżono informacje dotyczące życia zawodowego i prywatnego 26 postaci zuiązanych z polską oraz 10 z zagraniczną sceną polityczną. Wśród Polaków napisano między innymi o Barbarze Piwnik, Magdalenie Środzie, Joannie Kluzik-Rostouskiej, Eugeniuszu Kłopotku, Joannie Senyszyn, Tadeuszu Cymańskim, Elżbiecie Bieńkouskiej i Romanie Giertychu. Politycy obcokrajowcy byli reprezentowani przez: Hillary Clinton - trzy razy, Julię Tymoszenko, Cristinę Fernandez de Kircher, Billa de Blasio, Anne Hidalgo, Karin Wanngärd, Patricie de Lille, Clover Moore, Emmanuela Macrona i Brigitte Macron).

Podobne tendencje ukształtowały się „Zwierciadle”, periodyku należącym do polskiej spółki. Na jego łamach przedstawiono 16 postaci związanych z polską sceną polityczną, między innymi Marię Szyszkouską, Donalda Tuska, Różę Thun, Leszka Balcerowicza, Janusza Polikota, Radosława Sikorskiego, Jerzego Buzka. Na łamach czterech artykułów przybliżono syluetki czterech postaci z zagranicy. Tylko w tym periodyku pisano o Melenne Verveer, ambasador do spraw kobiet w rządzie USA ${ }^{50}$.

Redakcja „Twojego Stylu” przyjęła inną strategię w publikacji syluetek polityków. Można stuierdzić, że starano się zachować róunowagę między reprezentantami polskiej i zagranicznej sceny politycznej. W latach 1990-2018 przybliżono 28 sylwetek Polaków i 24 syluetki obcokrajowców. Cudzoziemcy, o których nie pisano na łamach innych periodyków, to: Edith Cresson $^{51}$, Alain Bry ${ }^{52}$, Borys Jelcyn i Naina Jelcyn ${ }^{53}$, Jackie Kennedy ${ }^{54}$, Madeleine Albright ${ }^{55}$, Gro Harlem Brundtland ${ }^{56}$,

\footnotetext{
50 Z. O’Brien, Naszym córkom jest tatwiej, „Zwierciadło” 2008, nr 8, s. 64-65.

${ }^{51}$ R. Wysocki, Ta trudna Paryżanka, „Twój Styl” 1991, nr 9, s. 38-41.

52 J. Bończyk, Codzienne święto, „Twój Styl” 1991, nr 7/8, s. 106-107.

${ }^{53}$ Ukryta w cieniu, „Twój Styl” 1992, nr 4, s. 158-159.

54 A. Ziółkouska-Boehm, Amerykańska ikona, „Twój Styl” 1992, nr 3, s. 151-153; M. Michałouska, Wieczny romans z milionami, „Twój Styl” 1993, nr 12, s. 178-181.

${ }_{55}$ K. Rusin, W łagodnych ostrych stowach, „Twój Styl” 1998, nr 3, s. 74-79.

${ }^{56}$ K. Hugosson-Bujwid, Moje bluzki prasuje mąż, „Twój Styl” 1998, nr 6, s. 74-76.
} 
Ruth Dreifuss ${ }^{57}$, Condolezza Rice ${ }^{58}$ oraz Tony Blair i Cherie Blair ${ }^{59}$. Polacy, którym tylko w „Twoim Stylu” poświęcono łamy, to: Barbara Olesińska-Turszyńska, Franciszka Cegielska, Barbara Labuda, Maria Wodzyńska-Walicka, Jolanta Szymanek-Deresz, Zyta Gilowska, Julia Pitera.

Trzecią grupę stuorzyły „Wysokie Obcasy. Extra” i „Uroda Życia”, w których preferowano polityków zuiązanych z zagraniczną sceną polityczną. Należy u tym miejscu podkreślić, że w przypadku tego drugiego magazynu materiał badawczy stanowiło jedynie sześć artykułów. Redakcja „Wysokich Obcasów. Extra” zdecydowanie postawiła na syluetki obcokrajowców. Przedstawiono 23 postaci z zagranicy (Księżna Diana, Vladimir Putin, Angela Merkel, Georg Bush, Barack Obama, Emmanuel Macron, Hillary Clinton, Michael Bachelet, Dalia Grybauskaite, Park Geln-Hye, Theresa May, Ellen Johanson, Erne Solberg, Kersti Kaijuland, Małgorzata II, Królowa Wiktoria, Donald Trump, Książe Karol, Księżna Alice Roosevelt, Jacinda Ardern, Winston Churchill, Alexandria Ocasio-Cortez) i sześć związanych z rodziną sceną polityczną (Wojciech Jaruzelski, Donald Tusk, Joanna Kluzik-Rostowska, Janusz Palikot, Aleksander Kuaśnieuski, Robert Biedroń. Marek Borouski).

Na łamach „Urody Życia” przedstawiono cztery postaci z zagranicy, tj. Hillary Clinton i Billa Clintona, Francois Mitteranda, Emmanuela Macrona oraz duie z polskiej, mianowicie Roberta Biedronia i Jacka Kuronia. Na rycinie 4 zilustrowano omawiane dane.



Rycina 4. Analiza porównawcza ze względu na narodowość Źródło: badania własne.

57 K. Wrubel, Podwójne życie, „Twój Styl” 2000, nr 1, s. 56-58.

58 A. Tomiak, Na dobre i zte Condi, „Twój Styl” 2002, nr 9, s. 74-78.

59 A. Tomiak, Superwoman jest zmęczona, „Twój Styl” 2003, nr 3, s. 78-80. 


\section{Podsumowanie}

Na łamach artykułu starano się przedstawić uyniki badań empirycznych dotyczących funkcjonowania prasy kobiecej na polskim rynku prasowym. Dokładniej zaś rzecz ujmując, uzupełnić lukę dotyczącą zagadnień związanych z polityką, prezentowaną przez pryzmat sylwetek postaci sprauujących władzę. Obszerność materiału nie pozwoliła na dogłębną analizę zarówno ilościową, jak i jakościową. Dlatego skoncentrowano się na przedstawieniu najważniejszych tendencji głównie o charakterze ilościouym.

Z przeprowadzonych badań wynika, że każdy z magazynów niezależnie od kapitału inwestującego stosował własne strategie w ilości publikacji prasowych dotyczących syluetek polityków. W latach 1990-2018 najczęściej rocznie ukazywało się od sześciu do ośmiu artykułów, które poświęcono jednej postaci. Teksty traktujące o więcej niż jednej postaci były domeną „Wysokich Obcasów. Ekstra”. Zarówno ze względu na płeć, jak i na pochodzenie polityka zaznaczyła się duża różnorodność. „Twój Styl”, „Pani”, „Wysokie Obcasy. Extra” zdecydowanie preferowały kobiety, natomiast „Zuierciadło” i „Uroda Życia” mężczyzn. Redakcja „Elle” zachowała niemal róunowagę. W każdym periodyku pojawiały się „ulubione” postaci, dla których łamy przeznaczano kilkukrotnie. Przybliżano także syluetki postaci, o których nie można było przeczytać $w$ żadnym innym magazynie luksusowym.

Także ze względu na narodowość tytuły podzieliły się na trzy grupy. Pieruszą stanowiły te, które preferują polityków reprezentujących polską scenę polityczną: „Pani”, „Elle”, „Zwierciadło”. „Twój Styl” starał się zachować róunowagę między obyduiema kategoriami. Do trzeciej należały „Wysokie Obcasy. Extra” i Uroda Życia” preferujące polityków z zagranicy.

Reasumując, ustępna analiza ilościowa jest przyczynkiem do szczegółowych, porównawczych badań - zarówno ilościowych, jak i jakościouych - w obrębie trzech subsegmentów należących do prasy kobiecej, tj. magazynów luksusowych, prasy true story i magazynów typu people. Po transformacji ustrojowej prasa adresowana do żeńskiego odbiorcy brała udział w prezentowaniu syluetek polityków, propagowała wzorce uprawiania polityki, w pewnym sensie brała udział w komunikowaniu politycznym.

\section{Bibliografia}

Źródła:

Adamowicz P., Danuta Watęsa, „Pani” 2009, nr 6.

Bednarska A., Bartoszewski bój się Boga, „Twój Styl” 2007, nr 5.

Bednarska M., Bezczelna optymistka, „Twój Styl” 2014, nr 4.

Bończyk J., Codzienne święto, „Twój Styl” 1991, nr 7/8.

Borowiec A., Gdy księżniczka się nudzi, „Wysokie Obcasy. Extra” 2013, nr 5.

Domagalik M., Byt kandydatem na maminsynka, „Pani” 2004, nr 2.

Domagalik M., Nie sztuka wygrać, gdy się jest najlepszym, „Pani” 2006, nr 1.

Domagalik M., Przyjemność, co ma pani na myśli, „Pani” 2004, nr 2.

Fabianouska-Micyk Z., Frasyniuk cośmy najlepszego zrobili, „Zwierciadło” 2011, nr 8. 
Feldman T.B., Chciałabym pogodzić świat, „Twój Styl” 2001, nr 3.

Giedrys G., Wizerunkowy turniej garbusów, „Wysokie Obcasy. Extra” 2015, nr 10.

Grigo A., Europa w rodzinie, „Twój Styl” 2002, nr 12.

Hankel B., Pielęgnowanie uczuć, „Pani” 2001, nr 5.

Henkel B., W młodości hierarchie tańcza jak zwariowane, „Pani” 2003, nr 7.

Henkel B., Wspólne chwile i rozterki, „Pani” 1994, nr 4.

Hrybacz B., Nie chciałam być sucha pania premier, „Pani” 1996, nr 12.

Hugosson-Bujwid K., Moje bluzki prasuje maż, „Twój Styl” 1998, nr 6.

Iwaszkiewicz N., Lubię świat i ludzi, „Pani” 2002, nr 4.

Iwaszkiewicz N., Między wyciągnięta dtonią na nie zerwanym jabłkiem, „Pani” 1994, nr 7/8.

Jaros M., Szczęście to w Róży, „Twój Styl” 2005, nr 12.

Kachka B., Bugajska A., Żona burmistrz i Nowy York, „Elle” 2014, nr 4.

Kłopotouski K., Kobieta z kauczuku, „Pani” 2000, nr 10.

Królikowaska-Avis E., Londyńska misja, „Twój Styl” 2002, nr 12.

Lipińska W., 10 pytań do dwojga, „Zwierciadło” 1996, nr 8.

Litorowicz-Siegert A., A państwo tak razem, „Twój Styl” 2016, nr 2.

Łopieńska B.N., Ztota próba, „Twój Styl” 1998, nr 9.

Michałouska M., Kobiety z przyszłościa, „Twój Styl” 1994, nr 10.

Michałouska M., Wieczny romans z milionami, „Twój Styl” 1993, nr 12.

Mroziewicz K., Zawsze pierwsza, zawsze dama, „Pani” 2007, nr 1.

Nogaś M., Underwood wygrałby z Trumpem, „Wysokie Obcasy. Extra” 2017, nr 5.

O’Brien Z., Naszym córkom jest tatwiej, „Zuierciadło” 2008, nr 8.

Pinkwart S., Portret wewnętrzny. Watęsa, „Pani” 2009, nr 10.

Plebanek G., Po władzę ze skalpelem, „Elle” 2013, nr 2.

Prezydentki, „Elle” 2016, nr 12.

Rachid Chehab M., Książe Karol i prognoza pogody, „Wysokie Obcasy. Extra” 2017, nr 9.

Rachid Chehab M., Lady gadżet, „Wysokie Obcasy. Extra” 2017, nr 9.

Romanouski A., Hillary wygrana Clintona, „Twój Styl” 1993, nr 2.

Rusin K., Konfrontacja rywalek, „Twój Styl” 1996, nr 11.

Rusin K., W łagodnych ostrych stowach, „Twój Styl” 1998, nr 3.

Ruszpel M., Lekcja feminizmu, „Zuierciadło” 2008, nr 8.

Staniszeuska M., Jagodowa księżniczka, „Wysokie Obcasy. Extra” 2017, nr 4.

Staszeuski W., Świat wedtug Zofii, „Twój Styl” 2017, nr 3.

Sulej K., Prezydencie nie wypada, „Wysokie Obcasy. Extra” 2017, nr 11.

Szczupeł B., Dom rodzinny Donalda Tuska, „Pani” 1992, nr 12.

Szmidt J., Codziennie rachunek, „Twój Styl” 1993, nr 4.

Szmidt J., Dobrze być soba, , „Twój Styl” 2015, nr 6.

Szmidt J., Zawsze gotowa, „Twój Styl” 2001, nr 2.

Tomiak A., Czas na pierwsze damy, „Twój Styl” 2004, nr 2.

Tomiak A., Na dobre i złe Condi, „Twój Styl” 2002, nr 9.

Tomiak A., Nie zobaczycie moich tez, „Twój Styl” 1998, nr 7.

Tomiak A., Superwoman jest zmęczona, „Twój Styl” 2003, nr 3.

Uderzamy dłonią $w$ dłoń, „Twój Styl” 1997, nr 1.

Ukryta w cieniu, „Twój Styl” 1992, nr 4.

Waloch-Matlakiewicz N., Luzuje gorset i robię swoje, „Wysokie Obcasy. Extra” 2016 nr 5.

Waloch-Matlakiewicz N., One rządza światem, „Wysokie Obcasy. Extra” 2016, nr 11.

Wężyk K., Kieszonkowy Herkules, „Wysokie Obcasy. Extra” 2017, nr 6. 


\section{Olga Dąbrowska-Cendrowska}

Wężyk K., Księżniczka Alice, „Wysokie Obcasy. Extra” 2017, nr 3.

Wlazły A., Ani słowa o polityce, „Twój Styl” 1999, nr 12.

Wrubel A., Podwójne życie, „Twój Styl” 2000, nr 1.

Wysocki R., Ta trudna Paryżanka, „Twój Styl” 1991, nr 9.

Ziółkouska-Boehm A., Amerykańska ikona, „Twój Styl” 1992, nr 3.

\section{Opracowania}

Adamik-Szysiak M., Grupa Bauer Media w Polsce. Działalność i kierunek rozwoju [w:] Inwestycje koncernów na polskim rynku medialnym. Wybrane zagadnienia, red. L. Pokrzycka, Wydawnictwo Uniwersytetu Marii Curie-Skłodouskiej, Lublin 2012.

Dąbrouska-Cendrouska O., Niemieckie koncerny prasowe w Polsce w latach 1989-2008. Działalność wydawnicza, upowszechnianie treści, sposoby oddziaływania na czytelników, Wydawnictwo Elipsa, Warszawa 2009.

Dąbrouska-Cendrouska O., W stronę sprofilowanego odbiorcy mediów, „Rocznik Bibliologiczno-Prasoznawczy" 2012, nr 15, s. 71-86.

Filas R., Polskie czasopisma w XXI wieku - rozwój czy kryzys, „Zeszyty Prasoznawcze” 2007, nr $1-2$, s. 7-41.

Gajlewicz-Korab K., Francuska prasa drukowana. Narodziny, rozwój, era cyfrowa, Wydawnictuo Aspra JR, Warszawa 2018.

Irimescu A.-O., Women's Magazines. Editorial practices and cultural recommendations, „Journal of Media Research” 2015, nr 8, s. 41-53.

Lisouska-Magdziarz M., Media powszechne. Środki komunikowania masowego i szerokie paradygmaty medialne $w$ życiu codziennym Polaków u progu XXI wieku, Wydawnictwo Uniwersytetu Jagiellońskiego, Kraków 2008.

Maj E., „Feminizm narodowy”, czyli o kobietach w Narodowej Demokracji [w:] Feminizm, red. M. Marczewska-Rytko, D. Maj, M. Pomarański, Wydaunictuo Uniwersytetu Marii Curie-Skłodouskiej, Lublin 2015, s. 216-229.

Menèndez M.I., Tipologia de la prensa femenina. Una propuesta de clacificatión, „Estudios sobre de Mensaje Periodistico" 2013, nr 1, s. 191-206.

Mielczarek T., Monopol, pluralizm, koncentracja. Środki komunikowania masowego w Polsce w latach 1989-2006, Wydawnictwa Akademickie i Profesjonalne, Warszawa 2007, s. 171-190.

Nieć M., Pisma opinii i czasopisma life style - dwie koncepcje rynkowego dziennikarstwa (analiza Polityki, Wprost, Elle, Playboya i Twojego Stylu), „Zeszyt Prasoznawcze” 2010, nr $1 / 2$, s. 23.

Reynolds Ch., LoRusso S., The Women's Magazines Diet: Frames and Sources in Nutrition and Fitness Articles, „Journal of Magazines and New Media Research” 2016, nr 1, s. 4-21.

Sokół Z., Prasa kobieca w Polsce w latach 1945-1995, Wydawnictwo Wyższej Szkoły Pedagogicznej, Rzeszóu 1995.

Wodniak K., Wspótczesna prasa kobieca a sprawy książki, Stowarzyszenie Bibliotekarzy Polskich, Warszawa 2004.

Zierkiewicz E., Czasopisma life-stylowe dla mężczyzn - (pozorna) opozycja dla prasy kobiecej, „Studia Socjologiczne” 2008, nr 1, s. 45-75.

Zierkiewcz E., Prasa jako medium edukacyjne. Kulturowe reprezentacje raka piersi w czasopismach kobiecych, Oficyna Wydawnicza Impuls, Kraków 2013.

Zierkiewicz E., Prasa kobieca versus pisma feministyczne. Między „dobrowolnym” zniewoleniem a „wymuszona" emancypację? [w:] Kobiety w kulturze popularnej, red. E. Zierkiewicz, I. Kowalczyk, Wydawnictwo Konsola, Wrocław 2002. 